\title{
EFEKTIVITAS PENYALURAN BANTUAN SOSIAL PEMERINTAH UNTUK MENGATASI DAMPAK COVID-19 DI INDONESIA
}

\author{
Noni Noerkaisar \\ Institut Pertanian Bogor
}

\begin{abstract}
The spread of the Covid-19 pandemic resulted in a domino effect for all the sectors starting from health issues to social issues, economic, and political. Facing this situation, the government has designed various Social Safety Network policies as an effort to protect susceptible and affected communities from the COVID-19 pandemic. The next problem that occurs is during social assistance which is disbursed by the government, such as the inaccurate targeting of social assistance recipients. Therefore, this study was conducted to analyze further the distribution effectiveness on social assistance provided by the government to overcome the impact because of Covid-19 pandemic in Indonesia. This study used a qualitative approach based on literature studies or research-oriented to the secondary information collected from various related sources. The results of this study showed that the social assistance distributed by the government is still not effective. It was because there were still inaccuracies in the social assistance recipients, unequal distribution of assistance, long distribution, misappropriation of funds, illegal levies, nominal amounts reduction, and resources received, errors inclusion and exclusion, to the social assistance politicization.
\end{abstract}

\begin{abstract}
Abstrak
Penyebaran wabah Covid-19 mengakibatkan efek domino bagi semua sektor yang berawal dari persoalan kesehatan ke persoalan sosial, ekonomi, hingga politik. Menghadapi situasi tersebut pemerintah telah merancang berbagai kebijakan Jaringan Pengaman Sosial dalam upaya melindungi masyarakat rentan serta terdampak dari pandemi Covid-19. Permasalahan selanjutnya yang senantiasa timbul saat bantuan sosial digelontorkan oleh pemerintah yakni adanya ketidaktepatan sasaran penerima bantuan sosial. Oleh karenanya riset ini dilakukan untuk menganalisis lebih lanjut efektivitas penyaluran bantuan sosial yang diberikan pemerintah untuk mengatasi dampak penyebaran Covid-19 di Indonesia. Penelitian ini menggunakan kaidah kualitatif berdasarkan studi literatur, yaitu kaidah riset yang berorientasi pada pengumpulan informasi sekunder dari bermacam sumber terkait. Hasil penelitian diketahui bahwa bantuan sosial yang disalurkan oleh pemerintah hingga saat ini masih belum efektif. Hal tersebut dikarenakan masih terdapat ketidaktepatan sasaran penerimaan bantuan, ketidakmerataan penyaluran bantuan, pendistribusian yang lama, penyelewengan dana, pungutan liar, pengurangan jumlah nominal maupun sumber daya yang diterima, inclusion dan exclusion error, hingga politisasi bantuan sosial.
\end{abstract}

Keywords: effectiveness, distribution, government's social aid, covid-19, Indonesia JEL Classification: N4, N9 


\section{PENDAHULUAN}

\section{Latar Belakang}

Tahun 2019 merupakan awal mula kemunculan wabah virus jenis baru yaitu corona virus (SARS-CoV-2) serta penyakitnya yang dinamakan corona virus disease 2019 (Covid-19). Semenjak itu, wabah tersebut semakin menyebar dan berkembang di seluruh penjuru negara termasuk Indonesia. Di Indonesia kasus virus corona pertama kali terjadi pada awal bulan Maret 2020 dan penyebarannya terus meluas. Merujuk informasi dari Satuan Tugas Penanganan Covid-19 yang tersaji pada Grafik 1, terkonfirmasi bahwa jumlah pasien positif terkena Covid-19 per tanggal 29 Maret 2021 yakni 743.198 pasien. Sebanyak $82.25 \%$ atau 611.097 pasien dinyatakan sembuh dan 22.138 pasien atau $2.97 \%$ terkonfirmasi meninggal. Penyebaran wabah Covid-19 mengakibatkan efek domino bagi semua sektor yang berawal dari persoalan kesehatan ke persoalan

sosial, ekonomi, hingga politik. Dapat dilihat dari Gambar 1, data Badan Pusat Statistik (BPS) mencatat penurunan pertumbuhan laju ekonomi Indonesia pada Triwulan II-2020 menjadi negatif sebesar -5,32\%. Sebelumnya, laju pertumbuhan ekonomi Indonesia pada Triwulan I-2020 sebesar 2,97\% atau mulai menandakan adanya perlambatan laju aktivitas perekonomian. Hasil pengamatan Lembaga Ilmu Pengetahuan Indonesia (LIPI) kepada 1.548 responden yang tersebar di 32 provinsi, mengungkapkan lebih dari 50 persen responden menghadapi kesulitan keuangan imbas dari pandemi Covid-19. Kebijakan Pembatasan Sosial Berskala Besar (PSBB) yang diimplementasikan pemerintah dalam upaya percepatan penanganan Covid-19 menjadi salah satu faktor perlambatan laju ekonomi selama pandemi

\section{Grafik 1. Perkembangan Kasus Covid-19 di Indonesia per Tanggal 29 Maret} 2021

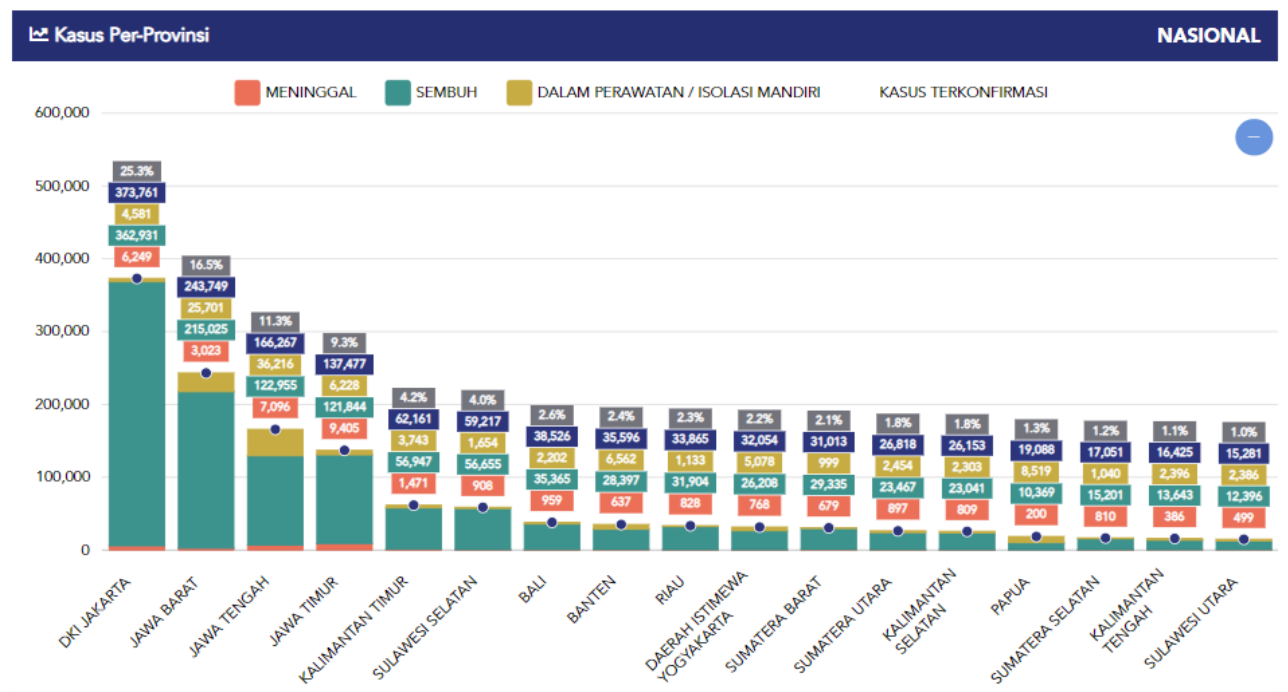

Sumber: Satuan Tugas Penanganan Covid-19, 2021 
berlangsung. Ruang gerak masyarakat yang dipersempit dalam melaksanakan aktivitas sehari-hari berdampak pada pemenuhan kebutuhan hidup. Meskipun demikian, physical distancing yang diterapkan pemerintah bukanlah tanpa alasan. Dengan semakin banyak masyarakat yang tetap tinggal di rumah, maka akan mengurangi penularan wabah Covid-19 secara masif (Lestary et al, 2020). Pemerintah Indonesia melaksanakan berbagai upaya untuk menghadapi pandemi. Berbagai kebijakan dirumuskan untuk melindungi masyarakat yang rentan juga terdampak pandemi Covid-19. Salah satunya dengan menerbitkan Undang-Undang Nomor 2 Tahun 2020 perihal Penetapan Peraturan Pemerintah Penganti Undang-Undang (Perppu) Nomor 1 Tahun 2020 tentang kebijakan keuangan negara serta kestabilan sistem keuangan dalam penanggulangan pandemi Covid-19 dan/atau dalam skema menghadapi ancaman yang dapat berpengaruh bagi perekonomian nasional dan/atau kestabilan sistem keuangan sebagai Undang-Undang.

Tujuan pembentukan Perppu Nomor 1 Tahun 2020 menurut Menteri Keuangan Sri Mulyani (2020) yaitu untuk memberi landasan hukum bagi pemerintah dalam menetapkan kebijakan dan langkah luar biasa atau extraordinary akibat pandemi Covid-19. Langkahlangkah tersebut diterapkan di bidang keuangan negara dan sektor keuangan dalam upaya penanganan krisis kesehatan, kemanusiaan, ekonomi, dan keuangan. Lebih lanjut Ketua Badan Anggaran DPR RI Said Abdullah (2020) menyatakan terdapat empat hal secara bersamaan pada Perppu Nomor 1 Tahun 2020 yang akan dilaksanakan pemerintah. Keempat hal tersebut adalah penanganan Covid-19, antisipasi terhadap sistem keuangan, stimulus ekonomi untuk usaha mikro kecil menengah (UMKM) dan koperasi, serta bantuan sosial.

Pembagian bantuan sosial yang diberikan pemerintah untuk masyarakat Indonesia bukanlah suatu hal baru. Beragam skema bantuan sosial serta subsidi telah dilaksanakan pemerintah untuk mencukupi hak dasar, meringankan tanggungan, dan memperbaiki tingkat hidup warga negara yang kurang berkecukupan. Hal ini sejalan dengan teori welfare state, merujuk dari Alfitri (2012) konsep welfare state dalam Encyclopedia Britannica yakni terkait tanggung jawab negara sebagai garda terdepan dalam melindungi serta memakmurkan kesejahteraan ekonomi dan sosial rakyatnya.

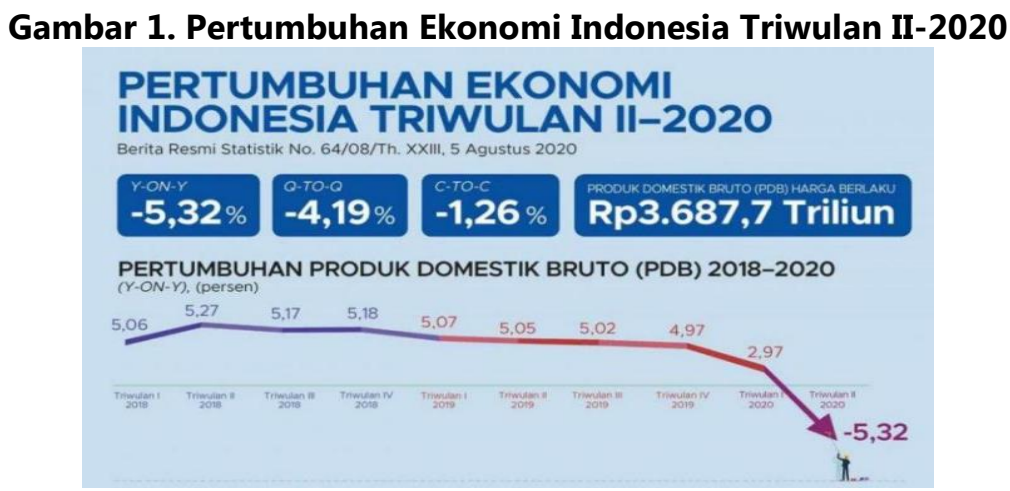

Sumber: Badan Pusat Statistik. 2020 
Di masa pandemi sekarang ini program Jaring Pengaman Sosial (JPS) berupa bantuan sosial sembako, bantuan sosial tunai, kartu prakerja, program keluarga harapan, dan subsidi listrik menjadi salah satu wujud intervensi pemerintah dalam upaya menanggulangi pengaruh Covid-19 terhadap masyarakat yang berpotensi terkena imbas sosial maupun ekonomi. Sumodiningrat (1999) memaparkan bahwa JPS sering kali menimbulkan permasalahan tersendiri. Dalam situasi krisis dan keterbatasan sumber dana, pelaksanaan program JPS akan menemui banyak hambatan. Tidak hanya itu, mengelola dana agar cepat dan tepat mengenai sasaran menjadi persoalan lain yang timbul saat dana tersedia dalam jumlah yang cukup. Teja (2020) juga mengungkapkan ketidaktepatan sasaran penerima bantuan sosial menjadi permasalahan yang senantiasa timbul saat bantuan sosial digelontorkan pemerintah. Selain itu, terdapat tumpang tindih program bantuan sosial COVID-19 yang dicetuskan pemerintah sehingga menyebabkan kesemrawutan dalam pelaksanaannya (Mufidah, 2020). Proses pendistribusian bantuan sosial pun dirasa belum optimal sampai ke masyakarat, dikarenakan sistem penunjang ketetapan yang masih samar dan juga ketidaksiapan pemerintah (Hirawan, 2020).

Di sisi lain Purnia et al (2019) mengungkapkan pemberian donasi bantuan sosial dari pemerintah pusat kerap disalahgunakan oleh pemerintah daerah. Ragam penyimpangan dilaksanakan dengan berbagai metode seperti membuat Lembaga Sosial Masyarakat (LSM) fiktif, sampai dengan kepentingan kampanye pemilihan kepala daerah. Sejalan dengan itu, hasil penelitian Negara dan Nuswardani (2014) menunjukkan

bahwa

adanya permasalahan terhadap penyaluran dana Bantuan Sosial oleh Pemerintah Provinsi yang diawali dengan tidak dilakukannya monitoring dan evaluasi kepada para penerima bantuan oleh Biro Kesejahteraan Rakyat. Tidak hanya di tingkat pemerintah daerah, lebih lanjut hal ini diperparah dengan penemuan kasus penyelewengan dana bantuan sosial Covid-19 yang terjadi terhadap pejabat negara di pemerintah pusat terkait penggunaan anggaran bantuan sosial dalam penanganan pandemi Covid-19 (CNN Indonesia, 2020).

Berdasarkan beberapa sumber dan riset terdahulu bisa ditarik benang merah bahwa sering terjadi permasalahan dalam penyaluran bantuan sosial pemerintah baik sebelum maupun pada saat pandemi. Permasalahan tersebut yang membuat penyaluran bantuan sosial menjadi tidak efektif sampai ke masyarakat. Berlandaskan penjabaran penelitian sebelumnya, terdapat perbedaan variabel dan hasil yang menjadi penyebab bantuan sosial pemerintah belum tersalurkan dengan maksimal kepada masyarakat yang membutuhkan. Dapat diketahui penelitian terdahulu hanya memfokuskan pengkajian di satu sisi saja, sehingga diperlukan suatu kajian lebih mendalam untuk membahas apakah penyaluran bantuan sosial pemerintah saat pandemi sudah berjalan maksimal. Oleh sebab itu, tujuan penelitian dilakukan untuk menganalisis efektivitas penyaluran bantuan sosial pemerintah untuk mengatasi dampak Covid-19 di Indonesia. Diharapkan pembahasan penelitian ini dapat memberikan wawasan terkait penyaluran bantuan sosial pemerintah saat pandemi Covid-19 berlangsung sehingga pada penelitian berikutnya 
mampu untuk memaparkan alternatif solusi yang lebih bervariasi dan inovasi agar penyaluran bantuan sosial pemerintah dapat berjalan dengan efektif.

\section{TINJAUAN LITERATUR}

\section{Bantuan Sosial}

Bantuan sosial (bansos) ialah pemberian santunan berbentuk donasi atau barang baik dari pemerintah maupun suatu lembaga kepada perorangan, keluarga, komunitas, dan rakyat umum yang sifatnya tidak selamanya serta selektif dengan tujuan untuk menyelamatkan dari kemungkinan terjadinya ancaman sosial (Sitanggang et al, 2014). Bantuan sosial yang disalurkan pemerintah kepada masyarakat prasejahtera merupakan bantuan sementara atau tidak bersifat terus menerus. Bantuan yang diberikan bertujuan agar masyarakat prasejahtera tersebut mampu mencukupi kehidupannya secara seimbang (Kementerian Sosial, 2011). Sejalan dengan hal tersebut Peraturan Menteri Keuangan (2015) menjelaskan bahwa bantuan sosial adalah pengeluaran berupa transfer uang, barang atau jasa yang diberikan oleh pemerintah kepada masyarakat miskin atau tidak mampu untuk melindungi masyarakat dari kemungkinan terjadinya resiko sosial, meningkatkan ekonomi dan/atau kesejahteraan masyarakat. Lebih lanjut Rahmansyah et al, (2020) memaparkan bahwasannya kebijakan bantuan sosial menjadi salah satu bentuk nyata tanggung jawab pemerintah baik pusat maupun daerah terhadap kondisi rakyatnya yang prasejahtera dan terabaikan di tingkat terendah.

Berdasarkan Peraturan Menteri Dalam Negeri Nomor 32 Tahun 2011, pemberian bantuan sosial memiliki standar ketetapan. Pemerintah daerah diperbolehkan memberi bantuan sosial untuk penduduk atau kelompok masyarakat setara dengan kemampuan keuangan daerah. Penduduk atau kelompok masyarakat tersebut meliputi (a) perorangan, keluarga, dan/atau masyarakat yang mengalami situasi yang tidak solid dampak dari kemelut sosial, ekonomi, politik, bencana, atau fenomena alam agar mampu mencukupi kebutuhan hidup minimum, (b) organisasi bukan pemerintah sektor pendidikan, keagamaan, dan sektor lainnya yang bertindak untuk mengayomi perorangan, kelompok, dan/atau masyarakat dari peluang terjadinya ancaman sosial.

Pembagian bantuan sosial sebagai halnya dipaparkan dalam Pasal 22 ayat (1) memenuhi standar paling minimal yaitu selektif dan mencakup kualifikasi penerima bantuan. Barometer kualifikasi penerima bantuan melingkupi mempunyai bukti jati diri, (2) bertempat tinggal dalam kawasan administratif pemerintah daerah sekitar, (3) bersifat tidak tetap dan hanya sementara, melainkan dalam kondisi tertentu dapat berkesinambungan, dan (4) sesuai target penerapan.

\section{Penyaluran Bantuan Sosial di Indonesia}

Mengutip Tim Nasional Percepatan Penanggulangan Kemiskinan (2020) bahwasanya, selama ini kendala yang sering terjadi dalam skema bantuan sosial ialah ketidaktepatan target penerima bantuan. Sejalan dengan hal tersebut, Santoso et al (2019) memaparkan ketidaktepatan target penerima acapkali ditemui saat mendistribusikan bantuan ke lapangan. Lebih lanjut Mufidah (2020) menyatakan 
bahwa beraneka ragam jenis bantuan sosial yang diadakan Pemerintah Pusat dan alur administrasi penyaluran bantuan sosial yang memusingkan membuahkan kekacauan seperti kesimpangsiuran informasi akan akses penerimaan bantuan sosial yang beredar di masyarakat. Tidak hanya itu, klasifikasi yang tidak sesuai dengan target dan jangka waktu pendistribusian bansos yang tidak serempak menjadi permasalahan yang tidak kunjung berakhir.

Bantuan sosial sepanjang pandemi Covid-19 berlangsung juga belum merangkul kelompok masyarakat yang sebelum adanya pandemi termasuk golongan masyarakat mampu, namun saat terjadi pandemi harus kehilangan penghasilan hingga kehilangan pekerjaannya (Tim Nasional Percepatan Penanggulangan Kemiskinan, 2020). Menteri Keuangan (2020) menekankan terdapat empat sektor yang paling terguncang dampak pandemi Covid-19, yakni bidang rumah tangga, karyawan lepas, UMKM, dan perusahaan atau badan usaha. Dari beberapa sektor tersebut, karyawanlah yang paling sensitif untuk kehilangan penghasilannya.

\section{METODOLOGI PENELITIAN}

\section{Jenis dan Sumber Data}

Metode kualitatif digunakan dalam penelitian ini, dimana penelitian terdahulu serta referensi-referensi lainnya yang bersifat analisis pustaka (library research) sebagai objek utama penelitian (Hadi, 1995). Data sekunder dihimpun dari beragam sumber, baik secara personal maupun instansi agar dapat menjawab pertanyaan yang telah dirancang sebelumnya (Qadri, 2019). Penghimpunan data dilakukan melalui pengumpulan informasi dari media elektronik berlandaskan website, baik berupa berita, artikel, dan penelitian terdahulu terkait penyaluran bansos baik sebelum dan saat Covid-19 berlangsung di Indonesia.

\section{Metode Pengolahan Data}

Data yang digunakan bersifat empiris, artinya hanya menghimpun informasi-informasi yang telah teruji kebenarannya (Rahmansyah et al, 2020). Data berasal dari suatu penelitian yang telah dilakukan sebelumnya dan juga berasal dari media massa online seperti portal berita, artikel, dan buku elektronik (e-book) yang dijadikan sebagai data pendukung untuk memperkuat pembahasan analisis. Data yang terkumpul dikembangkan sesuai dengan peraturan bantuan sosial dan kondisi lapangan. Data dianalisis dengan menerapkan kajian wacana untuk menelaah efektifitas pendistribusian dana bantuan sosial untuk mengatasi dampak penyebaran Covdi-19 di Indonesia.

\section{HASIL PENELITIAN DAN PEMBAHASAN \\ Bantuan Sosial Pemerintah Selama Pandemi Covid-19}

\section{Pemerintah memiliki beberapa} kebijakan untuk melindungi perekonomian rakyat melalui program Pemulihan Ekonomi Nasional (PEN) untuk penanganan pandemi Covid-19 (Sugiarto, 2020). Tak hanya berfokus pada pemberian sembako saja, bersama Kementerian Keuangan pemerintah pusat menciptakan sejumlah skema JPS atau Social Safety (Adhiyasa, 2020). Bersumber dari Badan Nasional Penanggulangan Bencana (BNPB), pemerintah pusat telah mengerahkan berbagai bentuk dan jenis kebijakan 
bantuan sosial dalam upaya pandemi Covid-19 berlangsung menyelamatkan ketahanan ekonomi (Kementerian Sosial, 2020). Selama masyarakat dalam menghadapi kondisi pandemi saat ini meliputi (1) Program Keluarga Harapan (PKH), (2) Bantuan Sosial Tunai, (3) Bantuan Langsung Tunai Dana Desa (BLT Dana Desa), (4) Bantuan Sosial Sembako (BSS) untuk Wilayah Jakarta Bogor Depok Tangerang dan Bekasi (Jabodetabek), (5) Kartu prakerja, (6) Kartu sembako, dan (7) Subsidi listrik. Gambaran mengenai kebijakan JPS Pemerintah Pusat dalam menghadapi pandemi COVID-19 dapat dilihat pada Gambar 2.

\section{Program Keluarga Harapan}

Bantuan sosial Program Keluarga Harapan (PKH) merupakan salah satu JPS untuk keluarga pra sejahtera. Tujuan PKH adalah memperkuat daya beli, meningkatkan nutrisi dan gizi, serta daya tahan tubuh anak, ibu hamil, disabilitas berat, dan orang lanjut usia. Selain itu juga untuk meningkatkan konsumsi masyarakat dan menjaga pendapatan serta pengeluaran keluarga pra sejahtera agar terhindar dari resiko sosial selama pandemi, penyaluran PKH mengalami kenaikan sebanyak 25\% dari 9.2 juta keluarga penerima manfaat (KPM) bertambah menjadi 10 juta KPM.

Adapun nominal bantuan PKH yang didistribusikan sebesar 250 ribu rupiah per bulan untuk kategori ibu hamil dan anak usia 0-6 tahun, 75 ribu rupiah per bulan untuk kategori siswa-siswi Sekolah Dasar (SD), 125 ribu rupiah untuk kategori siswa-siswi Sekolah Menengah Pertama (SMP), dan 166 ribu rupiah per bulan untuk kategori siswa-siswi Sekolah Mengah Atas (SMA). Sementara untuk kategori penyandang disabilitas berat dan peserta $\mathrm{PKH}$ berusia lebih dari 70 tahun ke atas memperoleh bantuan sebesar 200 ribu rupiah per bulan. Bantuan sosial PKH tersebut diberikan maksimal untuk empat jiwa dalam satu keluarga. Rincian mengenai peningkatan nominal dana PKH selama masa pandemi ini dapat dilihat pada Tabel 1 .

Terdapat modifikasi frekuensi dalam pendistribusian $\mathrm{PKH}$ di masa pandemi covid-19. Umumnya bantuan

\section{Gambar 2. Kebijakan Jaringan Pengaman Sosial Pemerintah Pusat dalam} Menghadapi Pandemi Covid-19

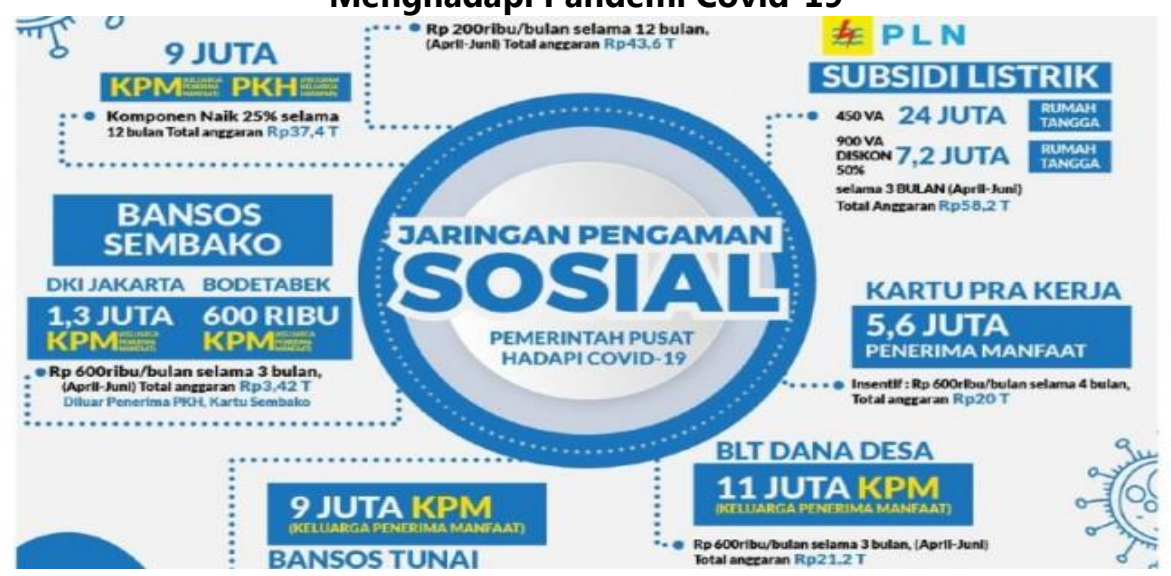

Sumber: Badan Nasional Penanggulangan Bencana (BNPB), 2020 
PKH disalurkan per triwulan pada bulan Januari, April, Juli, dan Oktober, namun saat pandemi pendistribusian bantuan diberikan setiap bulan dari April sampai Desember 2020. Bantuan akan ditransfer kepada Himpunan Bank Milik Negara (Himbara) seperti Bank Mandiri, BNI, BRI, dan BTN. Sedangkan bagi peserta yang tidak mempunyai rekening Bank Himbara, bantuan bisa diambil di $e$-warong atau agen bank (Hastuti et al, 2020).

Penyaluran bantuan sosial PKH di masa pandemi ini bukanlah tanpa masalah. Rahmansyah et al. (2020) memaparkan beberapa permasalahan yang terjadi di lapangan seperti penerima bantuan PKH yang sudah mangkat, pindah tempat tinggal, menikah di usia muda, cerai, putus sekolah, dan perubahan status yang tidak sesuai dengan ketentuan penerima bantuan. Adanya ketidaktepatan sasaran penerima PKH tersebut disebabkan oleh database yang tidak akurat karena tidak ter-update secara rutin (BBC Indonesia, 2020). Selain itu ditemukan penemuan permasalahan baru yaitu pemalsuan data kriteria penerima $\mathrm{PKH}$ oleh pendamping, aparat berwenang, maupun petugas bank penyalur bantuan di lingkungan penerima $\mathrm{PKH}$ yang berakibat dana bantuan diterima oleh oknum yang bukan penerima manfaat (Robot \& Toreh,
2020).

Kenaikan bantuan sosial PKH nyatanya belum merefleksikan prinsip keadilan bagi KPM, terutama bagi KPM yang nominal bantuannya kecil. Hastuti et al. (2020) menjelaskan bagi KPM yang hanya mempunyai satu komponen anak $\mathrm{SD}$, maka bantuan yang didapat tidak bertambah signifikan yaitu dari Rp180.000,00 menjadi Rp225.000,00 per triwulan, atau Rp75.000,00 per bulan. Nominal yang diperoleh jauh lebih kecil bila dibandingkan dengan bantuan sosial pandemi Covid-19 lainnya. Lebih lanjut Khudori (2020) menyatakan terdapat ketidakefektifan dalam frekuensi pencairan PKH yang semula per tiga bulan menjadi setiap bulan. Hal tersebut karena terdapat pemotongan biaya admin saat penarikan serta biaya transport untuk mengambil bantuan di Anjungan Tunai Mandiri (ATM).

Dari permasalahan di atas dapat disimpulkan bahwa pendistribusian dana PKH oleh pemerintah belum berjalan dengan efektif, dikarenakan masih ditemui manipulasi data juga penyelewengan bantuan. Kondisi ini memicu banyak ditemukannya penerima bantuan PKH fiktif, sehingga berimbas bagi masyarakat yang seharusnya menerima manfaat bantuan menjadi terabaikan dari kebijakan pemerintah.

Tabel 1. Rincian Peningkatan Nominal Dana PKH Selama Masa Pandemi Covid-19

\begin{tabular}{|l|c|c|}
\hline Komponen Bantuan & $\begin{array}{c}\text { Pra Covid-19 } \\
\text { (dalam rupiah) }\end{array}$ & $\begin{array}{c}\text { Pasca Covid-19 } \\
\text { (dalam rupiah) }\end{array}$ \\
\hline Ibu Hamil & $2.400 .000,00$ & $3.000 .000,00$ \\
\hline Anak Usia Dini & $2.400 .000,00$ & $3.000 .000,00$ \\
\hline SD & $900.000,00$ & $900.000,00$ \\
\hline SMP & $1.500 .000,00$ & $1.500 .000,00$ \\
\hline SMA & $2.000 .000,00$ & $2.000 .000,00$ \\
\hline Disabilitas Berat & $2.400 .000,00$ & $2.400 .000,00$ \\
\hline Lanjut Usia & $2.400 .000,00$ & $2.400 .000,00$ \\
\hline
\end{tabular}

Sumber: Bank Mandiri, 2020 (Data diolah) 


\section{Bantuan Sosial Tunai}

Bantuan Sosial Tunai (BST) disalurkan pemerintah semenjak awal mula terdeteksi penyebaran Covid-19 di Indonesia. BST memiliki perbedaan dengan kebijakan lainnya yaitu dengan menyasar sembilan juta rakyat kurang mampu di 33 provinsi selain wilayah Jabodetabek, baik yang telah ataupun belum terdaftar Data Terpadu Kesejahteraan Sosial (DTKS). Silalahi (2020) menjelaskan penerima BST ialah masyarakat yang tidak menerima bantuan PKH serta dianggap layak mendapatkan bantuan. Selain itu, masyarakat yang menerima BST merupakan individu yang terkena imbas langsung perekonomiannya akibat pandemi covid-19 juga sudah terdata melalui by name by address (BNBA), Nomor Induk Kependudukan (NIK) dan nomor handphone aktif.

Penyaluran BST dibagi menjadi dua gelombang terhitung dari bulan April sampai dengan Desember 2020. Gelombang pertama berada di bulan April s.d. Juni 2020, penerima BST memperoleh bantuan sebesar Rp600.000,00 per KK per bulan. Selanjutnya gelombang kedua penyaluran BST berlangsung dari bulan Juli s.d. Desember 2020 dengan jumlah nominal bantuan yang telah disetarakan menjadi Rp300.000,00 per KK per bulan. Sama halnya dengan kebijakan $\mathrm{PKH}$, penyaluran BST ke masyarakat pun menggunakan metode transfer ke rekening Bank Himbara setiap penerima manfaat. Sedangkan bagi masyarakat penerima BST yang tidak mempunyai rekening di Bank Himbara, bantuan akan disalurkan melalui PT Pos Indonesia (Kementerian Sosial, 2020).

Kenyataannya akses untuk menyalurkan BST kepada masyarakat tidak semudah aturan pemerintah. Indonesia for Global Justice (2020) menemukan kasus terkait bantuan sosial yang disalurkan di daerah Nusa Tenggara Timur dan Nusa Tenggara Barat. Didapati banyak data penerima ganda yang berakibat pada ketidakadilan dan ketidakmerataan penyaluran BST. Tidak sampai disitu, persoalan pun bertambah karena lamanya proses distribusi sehingga membuat bantuan yang datang sering terlambat jika dibandingkan dengan kota-kota lain di Indonesia.

Data yang belum terintegrasi dengan baik antara pemerintah pusat dan daerah mengakibatkan penyaluran BST ke masyarakat menjadi chaos. Merujuk pernyataan mantan Menteri Sosial Khofifah Indar Parawansa (2020), data bansos yang saat ini digunakan oleh pemerintah pusat bukanlah data teraktual. DTKS terakhir diverifikasi pada tahun 2015 sehingga data tersebut sudah tidak relevan. Ketidakselarasan data inilah yang berdampak pada penolakan penyaluran BST di Pemerintah Provinsi Jawa Barat oleh beberapa kepala desa di wilayah Sukabumi. Kepala desa tersebut menolak menerapkan pendistribusian BST dari Pemerintah Provinsi Jawa Barat. Hal ini terjadi karena data penerima BST yang tidak valid dan tumpang tindih dengan data masyarakat yang tercatat sebagai penerima bantuan $\mathrm{PKH}$ (Rahmansyah et al., 2020).

\section{Bantuan Langsung Tunai Dana Desa (BLT Dana Desa)}

Bantuan Langsung Tunai Dana Desa (BLT Dana Desa) diberikan pemerintah melalui Kementerian Desa Pembangunan Daerah Tertinggal, dan Transmigrasi (Kemendes PDTT) sebesar Rp22,4 triliun yang ditujukan kepada 12.487 .646 kelompok keluarga pra sejahtera. 
Kebijakan ini merupakan revisi dari Peraturan Menteri Desa PDTT Nomor 11 Tahun 2009 menjadi Peraturan Menteri Desa PDTT Nomor 6 Tahun 2020 tentang Aksentuasi Penerapan Dana Desa Tahun 2020 (Badan Pemeriksa Keuangan, 2020).

Menteri Desa, Pembangunan Daerah Tertinggal, dan Transmigrasi Abdul Halim Iskandar (2020) memaparkan target utama penerima BLT ialah keluarga prasejahtera yang bukan tercatat sebagai penerima PKH dan juga Bantuan Pangan Non Tunai (BPNT), yang tidak terdaftar dalam kartu prakerja, kehilangan penghasilan, belum terdata (exlusion error), serta memiliki anggota keluarga yang sakit menahun dan atau kronis. BLT Dana Desa disalurkan oleh pemerintah desa dengan sistem non tunai (cash less) setiap bulan. Jangka waktu pemberian BLT Dana Desa dilaksanakan selama sembilan bulan, terhitung dari bulan April hingga Desember 2020. Sedangkan untuk nominal BLT Dana Desa yang disalurkan per bulan April s.d. Juni 2020 sebesar Rp600.000,00 per keluarga dan pada bulan Juli s.d. Desember 2020 nominalnya disesuaikan menjadi Rp300.000,00 per keluarga (Suwiknyo, 2020).

Permasalahan pun terjadi dalam kurun waktu hampir tiga bulan setelah pemerintah menetapkan program BLT Dana Desa. Merujuk dari Khalid (2020) polemik terjadi di daerah Lombok Tengah, dimana penerima BLT Dana Desa Covid-19 hanya mendapatkan Rp150.000,00 dari jumlah nominal seharusnya yaitu sebesar Rp600.000,00. Sejalan dengan hal tersebut, pemotongan nominal BLT Dana Desa pun terjadi di Provinsi Riau. Pemotongan disebabkan oleh aturan administrasi pembuatan rekening bank serta ketentuan yang mewajibkan pemilik rekening untuk menyisakan saldo minimum (Tanjung, 2020). Tentunya hal tersebut mengurangi keefektifan manfaat yang diberikan oleh pemerintah.

Persoalan data pun terjadi tak terkecuali dalam jenis bansos ini. Bersumber dari Indonesia for Global Justice (2020), terdapat ketidaktransparanan data serta kesenjangan sosial yang terjadi di daerah Lampung dan Medan. Ditemukan bahwa terdapat ketidakjelasan penerima bantuan dan standar kriteria yang menurut penduduk setempat tidak lazim diberikan oleh pemerintah daerah sampai ke pejabat desa. Mendukung penyataan di atas, Novika (2020) mengungkapkan terdapat faktor politik masa lampau pada pendataan dan pendistribusian BLT Dana Desa. Kondisi tersebut terjadi dikarenakan pemangku kebijakan setempat hanya mendata dan memprioritaskan warga yang memilinya saat pemilu lalu.

\section{Bantuan Sosial Sembako untuk Wilayah Jabodetabek}

Bantuan sosial berbentuk sembako diberikan sejak awal terjadinya pandemi Covid-19 di Indonesia. Jenis bansos ini dikhususkan hanya bagi warga yang bertempat tinggal di daerah DKI Jakarta dan sekitarnya seperti Bogor, Depok, Tangerang, Tangerang Selatan, juga Bekasi yang terkena imbas dari penyebaran Covid-19 baik sudah terdaftar atau pun belum dalam Data Terpadu Kesejahteraan Sosial (DTKS) (Kementerian Sosial, 2020).

Umasugi (2020) memaparkan ditemukannya kendala dalam pendistribusian bansos sembako baik yang berasal dari Pemerintah Provinsi DKI Jakarta maupun Pemerintah Pusat terhadap warga yang terkena imbas 
pandemi Covid-19 di ibukota. Berdasarkan data hasil survei Koalisi Pemantau Bansos Jakarta (Wijaya, 2020), $70,16 \%$ responden menyatakan bansos sembako habis hanya dalam jangka waktu kurang dari satu minggu. Padahal seharusnya bansos sembako yang didistribusikan tersebut untuk memenuhi kebutuhan selama dua minggu sampai dengan satu bulan. Terdapat beberapa alasan yang menyebabkan bansos paket sembako mudah habis. Pertama isi paket bantuan berjumlah sedikit. Kedua penerima bansos paket sembako terdiri dari banyak anggota keluarga sehingga tidak sebanding dengan jumlah bansos. Selain itu, paket sembako yang diberikan pemerintah tidak mencakup kebutuhan masyarakat dalam menjaga kebersihan dan peningkatan imunitas. Tercermin dari isi paket bansos yang hanya menyediakan satu sabun mandi serta tidak terdapat asupan vitamin pada paket sembako tersebut. Lebih lanjut masalah bansos sembako Jabodetabek diperparah dengan adanya tindak penyelewengan dana bantuan paket sembako oleh pejabat Kementerian Sosial, yang seharusnya menjadi garda utama pemerintah dalam melaksanakan kebijakan penyaluran bantuan sosial (Indonesia Corruption Watch, 2020).

\section{Kartu Prakerja}

Kartu prakerja merupakan program peningkatan kapabilitas yang ditujukan bagi para pencari kerja atau pekerja yang tersandung Pemutusan Hubungan Kerja (PHK), dan/atau pekerja atau buruh yang memerlukan peningkatan keahlian (Prakerja, 2020). Untuk dapat bergabung dalam program Kartu Prakerja, seseorang harus lulus melalui proses pendaftaran online, tes minat dan juga bakat, serta seleksi batch berdasarkan tempat tinggal.
Setelah menyelesaikan pelatihan, peserta memperoleh insentif yang didistribusikan menggunakan $e$-wallet atau rekening bank yang sudah didaftarkan sebelumnya (Fitriani, 2020).

Setiap peserta prakerja mendapatkan total bantuan berjumlah Rp3.550.000,00. Nominal tersebut untuk voucher pemelajaran senilai Rp1.000.000,00, penuntasan pemelajaran sebesar Rp600.000,00 per bulan selama empat bulan, dan survei kebekerjaan yang secara total berjumlah Rp150.000,00. Selama masa wabah Covid-19, peserta hanya diperbolehkan mengambil pelatihan online di platform semacam Tokopedia, Bukalapak, Skill Academy oleh Ruang guru, Mau Belajar Apa, Haruka Edu, Pijar Mahir, Sekolah.mu, dan Sisnaker (Prakerja, 2020).

Kepala Divisi Ekonomi Centre for Strategic and International Studies (CSIS) Yose Rizal Damuri mengungkapkan program Kartu Prakerja mungkin tidak dapat diharapkan untuk menjadi elemen bantuan yang efektif dimasa pandemi Covid-19. Menurutnya, insentif yang diberikan pemerintah hanya meliputi sebagian kecil total pengeluaran masyarakat. Mengacu pada data Badan Pusat Statistik Maret 2019, masyarakat yang masuk dalam kategori pra sejahtera memiliki rata-rata pengeluaran sebesar Rp425.250,00 per bulan. Sedangkan pengeluaran makan mereka rata-rata sebesar Rp313.323,00 per bulan atau setara dengan $73 \%$ dari total pengeluaran. Sementara itu, pelatihan online memerlukan listrik dan internet, artinya pengeluaran untuk komponen tersebut membengkak.

Mendukung pernyataan di atas, Lestary et al. (2020) pada penelitiannya menjelaskan meskipun pemerintah telah berupaya melonggarkan syarat dengan 
mengharuskan pelatihan secara online, calon peserta belum tentu terbiasa dengan platform tersebut. Jenis pelatihan hard-skill seperti menjahit, menenun, memasak, dan lain-lain menjadi tantangan tersendiri untuk dilakukan karena keperluan membeli alat dan bahan. Masalah pun tak berhenti disitu saja, disisi lain sebagian peserta kartu prakerja berkeluh kesah terkait insentif yang dijanjikan karena tak kunjung cair padahal peserta sudah merampungkan pelatihan. Keluhan juga muncul dari segi teknis terkait lisensi yang masih belum terlampir pada laman dashboard akun partisipan (Thomas, 2020).

\section{Kartu Sembako}

Kartu Sembako ialah kebijakan pemerintah melalui Kementerian Sosial dengan nama terdahulunya yakni Bantuan Pangan Non Tunai atau disingkat BPNT. Kartu sembako diberikan kepada keluarga prasejahtera yang rentan terhadap imbas pandemi Covid19 dan terdaftar dalam Data Terpadu Kesejahteraan Sosial (Kementerian Sosial, 2020). Ketua Tim Pengurus Penerapan Pendistribusian Bantuan Sosial Non tunai Muhadjir Effendi (2020) menyatakan, Program Sembako diterapkan di seluruh daerah di Indonesia termasuk juga kawasan yang mempunyai kelemahan dari segi infrastruktur, kendala telekomunikasi, dan akses geografis. Tentunya diperlukan treatment khusus untuk menyalurkan sembako di wilayahwilayah dengan kendala akses tersebut.

Pusat Pelayanan Sosial menjelaskan, pendistribusian dana program sembako menggunakan mekanisme uang elektronik dengan alat bantu pembayaran berupa Kartu Keluarga Sejahtera (KKS). Dana pada kartu sembako tidak bisa ditarik tunai dan hanya bisa digunakan untuk membeli komoditas bahan konsumi yang sudah ditetapkan dalam program sembako di Elektronik Warung Gotong Royong (eWarong). Saat ini terdapat beragam varian komoditas bahan pangan yang bisa dibelanjakan oleh masyarakat. Bila sebelumnya masyarakat hanya dapat berbelanja sembako berupa beras atau telur, sekarang masyarakat memliki banyak pilihan untuk membelanjakan bahan pangan lainnya seperti kabrohidrat (singkong, jagung, ubi, sagu, serta umbi-umbian lainnya), protein hewani (daging ayam, daging merah, ikan), protein nabati (tahu, tempe, juga kacang-kacangan), dan vitamin mineral seperti sayur-mayur serta buah-buahan (Febriana, 2020).

Kebijakan bantuan sosial baik berupa tunai maupun sembako merupakan program yang saat ini sangat dibutuhkan oleh rakyat. Sayangnya masih terjadi masalah dalam penerepannya dilapangan, seperti contoh kasus di Balai Gudang Rakyat Kota Depok. Di gudang rakyat tersebut terdapat tiga ratus $\mathrm{kg}$ telur ayam sisa bansos yang membusuk karena tidak disalurkan ke masyarakat lantaran kesemrawutan data yang diakibatkan oleh tumpang tindih data penerima bansos. Selain telur busuk, terdapat 4.200 paket bantuan sembako yang juga belum disalurkan dan berpeluang kadaluarsa (Ridhoi, 2020). Sedangkan di Desa Srigading, Bantul Yogyakarta, salah seorang penduduk tidak dapat menggunakan kartu sembako lantaran jumlah besaran dana yang disalurkan ke rekening penerima tidak sesuai nominal seharusnya. Setelah diselidiki hal tersebut disebabkan karena adanya kesalahan dalam penginputan besaran nominal. Seharusnya saldo yang didistribusikan berjumlah Rp200.000,00 
namun saat penerima manfaat memeriksa rekening jumlahnya hanya sebesar Rp 000.002 (Syarifudin, 2020).

\section{Subsidi Listrik}

Pemerintah

memberikan

pembebasan tagihan listrik untuk 24 juta pelanggan 450 VA dan diskon $50 \%$ untuk tujuh juta pelanggan daya 900 VA, sebagaimana fokus pemerintah untuk melindungi masyarakat lapisan bawah di tengah meluasnya penyebaran wabah Covid-19. Subsidi dibagikan dalam kurun waktu sembilan bulan, dimulai dari bulan April sampai dengan Desember 2020 (Kementerian Energi dan Sumber Daya Mineral, 2020).

Tim Nasional Percepatan Penanggulangan Kemiskinan (TNP2K) membeberkan 50\% penerima manfaat subsidi listrik adalah pelanggan rumah tangga yang termasuk golongan mampu. Bahkan yang menjadi miris adalah kenyataan bahwa masyarakat prasejahtera dan rentan yang masuk dalam kelompok $40 \%$ ekonomi terbawah hanya $26 \%$ diantaranya menerima subsidi listrik. Selain itu permasalahan lain yang terjadi pada jenis bansos subsidi listrik yakni banyaknya masyarakat yang tidak berhasil menggunakan subsidi ini disebabkan kesalahan saat memasukan format ID Pelanggan yang tertera di meteran. Kurangnya sosialisasi terkait cara pendaftaran dan penggunaan berdampak pada ketidakefektifan bantuan subsidi listrik (Abbas, 2020). Berdasarkan informasi sebelumnya dapat disimpulkan bahwa masih banyak pelanggan di kelas menengah bawah yang belum menerima manfaat kebijakan tersebut meskipun mereka turut terkena imbas dari pandemi Covid-19.

Efektivitas Penyaluran Bantuan Sosial Pemerintah Untuk Mengatasi Dampak Covid-19 di Indonesia

Menurut

Kurniawan

(2008), efektivitas adalah kemampuan melaksanakan tugas, fungsi (operasi kegiatan program atau misi) dari suatu organisasi atau sejenisnya yang tidak adanya tekanan atau ketegangan dalam pelaksanaannya. Efektivitas juga merupakan kolerasi derajat keberhasilan suatu operasi pada area publik. Suatu aktivitas bisa dikatakan efektif bila aktivitas tersebut memiliki dampak yang besar terhadap kemampuan menyediakan pelayanan masyarakat yang menjadi sasaran utama (Beni, 2016). Sebagaimana yang telah dijelaskan sebelumnya, program JPS merupakan kebijakan pemerintah untuk mengatasi dampak pandemi Covid-19 terhadap masyarakat. Kebijakan tersebut merupakan agenda mendesak jangka pendek yang dilaksanakan pemerintah untuk meminimalisir akibat jangka panjang dari penyebaran Covid-19. Dapat diketahui dari analisis literatur dan juga fakta-fakta yang terjadi di lapangan bahwasanya penyaluran bantuan sosial pada program JPS masih memiliki beberapa kendala yang mengakibatkan ketegangan dalam pelaksanaannya sehingga hal tersebut tidak sejalan dengan konsep teori efektivitas. Adapun pemetaan terkait kendala yang terjadi dalam penyaluran bantuan sosial pemerintah dapat dilihat pada Tabel 2 . 
Tabel 2. Pemetaan Kendala dalam Penyaluran Bantuan Sosial Pemerintah Selama

Pandemi Covid-19

\begin{tabular}{|c|c|c|c|c|c|c|c|c|}
\hline No & Permasalahan & PKH & $\begin{array}{c}\text { Bantuan } \\
\text { Sosial } \\
\text { Tunai } \\
\end{array}$ & $\begin{array}{c}\text { BLT } \\
\text { Dana } \\
\text { Desa } \\
\end{array}$ & $\begin{array}{l}\text { Bantuan } \\
\text { Sembako }\end{array}$ & $\begin{array}{l}\text { Kartu } \\
\text { Prakerja }\end{array}$ & $\begin{array}{c}\text { Kartu } \\
\text { Sembako }\end{array}$ & $\begin{array}{l}\text { Subsidi } \\
\text { Listrik }\end{array}$ \\
\hline 1 & Pemotongan/pungli & & & & & & & \\
\hline 2 & $\begin{array}{l}\text { Tidak didapatkan/ tidak } \\
\text { tepat sasaran }\end{array}$ & & & & & & & \\
\hline 3 & $\begin{array}{l}\text { Nominal/jumlah bantuan } \\
\text { kecil }\end{array}$ & & & & & & & \\
\hline 4 & Tumpang tindih data & & & & & & & \\
\hline 5 & Distribusi terhambat & & & & & & & \\
\hline 6 & Politisasi & & & & & & & \\
\hline 7 & Kualitas bantuan rendah & & & & & & & \\
\hline 8 & Penyalahgunaan dana & & & & & & & \\
\hline 9 & Insentif tidak cair & & & & & & & \\
\hline 10 & Human error & & & & & & & \\
\hline 11 & $\begin{array}{l}\text { Karakteristik permasalahan } \\
\text { lainnya yang diidentifikasi } \\
\text { penulis dari data sekunder } \\
\text { (kurangnya sosialisasi } \\
\text { bantuan) }\end{array}$ & & & & & & & \\
\hline 12 & Jenis bantuan tidak tepat & & & & & & & \\
\hline
\end{tabular}

Sumber: Data diolah oleh penulis, 2021

Berdasarkan hasil pemetaan pada Tabel 2, teridentifikasi ketidaktepatan sasaran menjadi permasalahan utama yang sering muncul di hampir setiap program bantuan sosial yang diberikan pemerintah. Ketidaktepatan sasaran disebabkan karena data yang tidak terupdate secara rutin baik di tingkat daerah maupun pemerintah pusat. Sejalan dengan hal tersebut, merujuk hasil riset Saiful Mujani Research \& Consulting (SMRC) yang dilaksanakan per tanggal 5 s.d. 6 Mei 2020, diketahui 49\% responden menilai bantuan sosial masih belum tepat sasaran. Sementara hanya $37 \%$ responden yang menilai bansos pemerintah sudah mencapai sasaran. Data tersebut menunjukan bantuan sosial yang disalurkan pemerintah untuk penanganan Covid-19 di Indonesia belum berjalan dengan maksimal. Penyaluran bantuan sosial dirasa belum tepat sasaran karena $60 \%$ responden menyatakan masih adanya warga yang belum mendapatkan bansos meskipun seharusnya warga tersebut berhak dan $29 \%$ responden beranggapan bansos yang diberikan salah sasaran. Selain itu 4\% responden beranggapan besaran bantuan yang diberikan terlalu kecil sehingga menjadi alasan mengapa bansos pemerintah tidak tepat sasaran. Alasan responden menilai bansos Covid19 tidak tepat sasaran dapat dilihat pada Gambar 3.

Sejalan dengan survei SMRC, hasil pemantauan Indonesia Corruption Watch (ICW) dimulai dari 2 Juni hingga 31 Agustus 2020 mendeteksi beberapa kendala dan presumsi penggelapan bansos Covid-19 yang dikeluarkan oleh pemerintah, seperti pemotongan atau pungli sebesar 19,25\%, inclusion error $17,99 \%$, bantuan tidak didapatkan warga 9,62\%, tumpang tindih bantuan 8,79\%, dan pendistribusian bantuan terhambat $4,60 \%$. Lebih lanjut dalam ICW menemukan beberapa kendala lain seperti politisasi $3,77 \%$, sembako tidak memenuhi syarat $0,84 \%$, kendala penyalahgunaan lainnya $16,32 \%$, dan non penyalahgunaan 18,82\% (Firmansyah, 2020). 

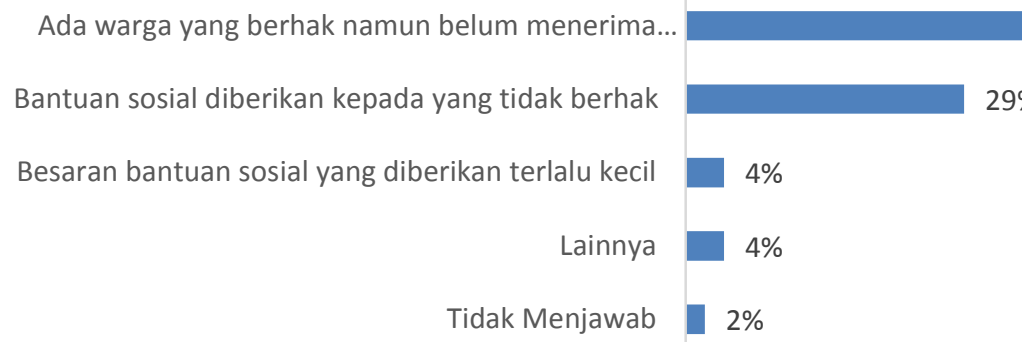

Sumber: Survei SMRC, 2020 (Data diolah)

Apabila analisis literatur dan data hasil survei SMRC serta ICW dikaitkan dengan teori efektivitas, maka didapatkan hubungan belum tercapai secara maksimal keberhasilan penyaluran bantuan sosial pemerintah dalam pengendalian Covid-19 kepada masyarakat rentan dan terdampak. Masih ditemukannya masalah di setiap jenis bansos yang diberikan, menjadi penyebab ketidaksesuaian output dengan tujuan yang ditetapkan. Keadaan ini diperparah dengan adanya kasus korupsi bansos sembako Covid-19 yang melibatkan pejabat Kementerian Sosial yang menjadi bukti bahwa program bantuan sosial rawan akan penyelewengan.

\section{KESIMPULAN DAN SARAN Kesimpulan}

Berdasarkan hasil observasi dan analisa terhadap literatur, berita, serta referensi terkait pendistribusian bantuan sosial pemerintah selama pandemi Covid-19 berlangsung, bisa disimpulkan bahwasanya bantuan sosial yang disalurkan pemerintah sampai dengan saat ini belum berjalan efektif. Masih terdapat permasalahan yang ditemui hampir diseluruh lini JPS baik dari hulu hingga ke hilir. Dari hulu, persoalan yang timbul terkait validitas data penerima bansos. Sedangkan dari hilir ditemukan beberapa permasalahan yang terjadi, diantaranya ketidaktepatan sasaran dalam penerimaan bantuan, penyaluran bantuan yang tidak merata, proses distribusi yang memerlukan waktu lama untuk sampai kepada penerima manfaat, penyelewengan dana, pungutan liar serta adaya pengurangan jumlah nominal maupun sumber daya yang diterima, inclusion dan exclusion error disebabkan pendataan yang tidak diperbaharui, hingga politisasi.

Ketidakandalan basis data merupakan faktor utama permasalahan pendistribusian bantuan sosial pemerintah di saat pandemi Covid-19. Diketahui dari pembahasan sebelumnya, Data Terpadu Kesejahteraan Sosial (DTKS) diperbarui secara masif pada tahun 2015. Padahal jika mengacu pada Pasal 8 Ayat 5 Undang-Undang Nomor 13 Tahun 2011 berkenaan pengurusan masyarakat pra sejahtera, dijelaskan semestinya verifikasi dan validasi data dilaksanakan secara periodik sekurang-kurangnya 2 tahun sekali. Bukan tanpa alasan DTKS harus selalu dimutakhirkan secara rutin. Mengingat peran dan fungsi DTKS selaku rujukan utama dalam menyejahterakan masyarakat Indonesia. Terlebih di saat pandemi Covid-19 berlangsung, DTKS 
menjadi tumpuan dalam penyaluran beragam skenario bantuan sosial.

\section{Saran}

Pada dasarnya tidak terdapat suatu model atau formula baku yang dapat digunakan sebagai acuan dalam mengimplementasikan JPS. Oleh karenanya nilai-nilai transparansi dan akuntabilitas diperlukan dalam tata laksana penyaluran bantuan sosial pemerintah di masa pandemi ini. Tata laksana yang diharapkan dalam hal ini yaitu mampu memenuhi unsur komunikasi, koordinasi, serta kolaborasi yang harmonis secara horisontal maupun vertikal. Dari segi horisontal berhubungan dengan kolaborasi antar lembaga atau institusi yang sama kedudukannya, seperti aliansi kementerian dan lembaga negara yang terkait. Sedangkan dari segi vertikal diperlukan kolaborasi yang selaras antar lembaga atau institusi dengan hierarki yang berbeda, seperti kerja sama pemerintah pusat dan daerah.

Mekanisme social control melalui peran aktif masyarakat dalam mengawal pendistribusian bantuan sosial pemerintah diperlukan untuk mengoptimalkan manfaat bansos. Peran aktif masyarakat yang dimaksud yaitu dengan berinisiatif melaksanakan registrasi mandiri yang bertujuan untuk self-reporting melalui bantuan unit pemerintahan terkecil seperti Rukun Tetangga (RT), Rukun Warga (RW), Camat, Lurah dan perangkat lainnya agar Data Terpadu Kesejahteraan Sosial (DTKS) dapat tervalidasi lebih cepat. Selain itu sosialisasi secara masif dan detail oleh pemerintah terkait prosedur penyaluran bansos diperlukan untuk memberikan pemahaman kepada masyarakat penerima manfaat.
Penggunaan teknologi dan informasi pun memberi peran penting selama menyalurkan bantuan sosial di masa pandemi Covid-19. Transformasi digital yang begitu cepat harus dimanfaatkan dengan optimal saat melakukan distribusi bantuan sosial kepada masyarakat. Digitalisasi data bantuan sosial yang terintegrasi dengan banking system perlu dilaksanakan untuk meminimalisir celah korupsi, gratifikasi, dan pungutan liar diseluruh skema dan unit penyaluran bantuan sosial pemerintah. Bantuan sosial yang diterima langsung oleh masyarakat diharapkan dapat meningkatkan daya beli dan konsumsi masyarakat sehingga hal tersebut dapat mendorong pemulihan ekonomi nasional.

Bantuan sosial sejatinya bermaksud untuk melindungi dan meningkatkan kesejahteraan hajat hidup masyarakat. Meskipun bantuan sosial tidak menjadi gagasan utama dalam mengatasi persoalan sosial dan ekonomi dimasa pandemi ini, namun hidup beriringan dengan mendahulukan tindakan saling peduli, berbagi, tenggang rasa, serta tolong-menolong menjadi faktor utama untuk mencapai kesejateraan sosial bagi masyarakat.

\section{IMPLIKASI DAN \\ KETERBATASAN}

\section{Implikasi}

Implikasi praktis pada penelitian ini diharapkan dapat memberikan kemaslahatan bagi pemerintah pusat dan daerah sebagai pemangku kepentingan JPS di masa pandemi Covid-19. Selain itu, hubungan dengan mitra pemerintah selaku distributor barang dan jasa pun harus dikukuhkan agar terjalin kerja sama 
yang harmonis untuk meminimalisir permasalahan ketersediaan barang.

Selanjutnya berdasarkan hasil analisis pada penelitian dapat dikemukakan implikasi teoritis terkait efektivitas penyaluran bantuan sosial pemerintah yang kenyataannya masih belum mencapai tujuan maksimal seperti yang diharapkan. Hal ini tidak hanya terjadi saat penyaluran bansos dalam program JPS Covid-19. Ketidakefektifan juga terjadi pada program bansos sebelum adanya Covid-19. Salah satu faktor utama disebabkan oleh ketidakandalan DTKS yang tidak terupdate secara rutin sehingga berdampak kepada ketidaktepatan sasaran penerima bansos. Selain itu, pungutan liar atau pemotongan bantuan dan penyalahgunaan dana yang terjadi di lapangan mengakibatkan penurunan jumlah manfaat bansos yang diterima oleh masyarakat. Kondisi tersebut membuat penyaluran bansos pemerintah ke masyarakat belum tercapai dengan baik.

\section{Keterbatasan}

Penelitian ini merupakan penelitian yang hanya menggunakan buku-buku dan juga literatur lainnya sebagai objek utama penelitian. Selain itu dokumentasi data yang tersedia pun terbatas pada beberapa berita yang ditriangulasi dengan beberapa sumber sekunder lainnya. Untuk penelitian selanjutnya, direkomendasikan dapat melakukan survey dan wawancara langsung ke objek penelitian yakni masyarakat penerima manfaat bansos. Hal tersebut bertujuan untuk mendapatkan informasi lebih mendalam dan menghasilkan data yang memberikan representasi lebih baik terkait efektivitas penyaluran bantuan sosial pemerintah.

\section{REFERENSI}

Abbas, F.P. (7 Mei 2020). Apa Masalahnya Banyak yang Gagal Terima Subsidi Listrik 900 VA dan 1.300 VA. Tribun Cirebon. Diakses pada tanggal 15 Juni 2021 dari

https://cirebon.tribunnews.com/202 0/05/07/apa-masalahnya-yabanyak-yang-gagal-terima-subsidilistrik-900-va-dan-1300-va-dariycab

Adhiyasa, D. (29 Mei 2020). Selain sembako, ini daftar bansos pemerintah pusat saat pandemi corona. Viva. Diakses pada tanggal 15 Juni 2021 dari https://www.viva.co.id/berita/nasion al/1218583-selain-sembakoinidaftar-bansos-pemerintah-pusatsaat-pandemi-corona

Alfitri. (2012). Ideologi welfare state dalam dasar negara Indonesia: analisis putusan mahkamah konstitusi terkait sistem jaminan sosial nasional. Jurnal Konstitusi 9, (3).

Badan Nasional Penanggulangan Bencana. (2020). Skema Pemberian Bantuan untuk Masyarakat Terdampak Pandemi COVID-19. Diakses pada tanggal 15 Juni 2021 dari

https://bnpb.go.id/berita/skemapemberian-bantuan-untukmasyarakat-terdampak-pandemicovid19

Badan Pusat Statistik. (2020). Pertumbuhan ekonomi Indonesia triwulan II 2020. Diakses pada tanggal 15 Juni 2021 dari https://www.bps.go.id/website/imag es/Pertumbuhan-EkonomiIndonesia-TW-II-2020-ind 
Bank Mandiri. (2020). Panduan jawaban bantuan sosial program sembako selama masa pandemic covid-19. Diakses pada tanggal 15 Juni 2021 dari https://www.bankmandiri.co.id/bans os

Beni, P. (2016). Konsep dan analisis efektivitas pengelolaan keuangan daerah di era otonomi. Jakarta: Taushia

CSIS: Kartu prakerja \& UU ciptaker solusi yang melengkapi. (27 Februari 2021). CNBC Indonesia. Diakses pada tanggal 15 Juni 2021 dari https://cnbcindonesia.com/news/202 10227113451-4-226600/csis-kartuprakerja-uu-ciptaker-solusi-yangmelengkapi

Ekonomi pandemi: Penyaluran bantuan sosial 'ke orang yang sudah meninggal', skema kebijakan dinilai 'tidak tepat sasaran'. (24 April 2020). BBC News Indonesia. Diakses pada tanggal 15 Juni 2021 dari https://www.bbc.com/indonesia/ind onesia-52399147

Enam masalah penyaluran bansos selama pandemi corona. (9 Oktober 2020). CNN Indonesia. Diakses pada tanggal 15 Juni 2021 dari https://www.cnnindonesia.com/ekon omi/20201008201256-532-

556227/6-masalah-penyaluranbansos-selama-pandemi-corona

Febriana, E. (2020). Program sembako untuk masyarakat rentan hadapi pandemi covid. Diakses pada tanggal 15 Juni 2021 dari https://puspensos.kemensos.go.id/p rogram-sembako-untukmasyarakat-rentan-hadapipandemi-covid-19

Firmansyah, L. M. (7 Desember 2020). Bansos sembako rawan korupsi, tak efektif bagi ekonomi. Lokadata. Diakses pada tanggal 15 Juni 2021 dari https://lokadata.id/artikel/bansossembako-rawan-korupsi-tak-efektifbagi-ekonomi

Fitriani, F. F. (16 April 2020). Ekonom CSIS: Kartu prakerja tidak efektif, lebih baik fokus bansos. Bisnis Indonesia. Diakses pada tanggal 15 Juni 2021 dari https://ekonomi.bisnis.com/read/20 200416/9/1228251/ekonom-csiskartu-prakerja-tidak-efektif-lebihbaik-fokus-bansos-

Hadi, S. (1995). Metodologi research. Yogyakarta: Fak.Psikologi UGM.

Hastuti, Ruhmaniyanti, \& Widyaningsih, D. (2020). Pelaksanaan PKH dan program sembako dalam rangka mitigasi covid-19. Catatan Penelitian Smeru, no,2/2020.

Hirawan, F. B. (2020). Optimizing the Distribution of the Social Assistance Program during the COVID- 19 Pandemic. CSIS Commentaries DMRU-081-EN/ ECON-003-EN. Diakses pada tanggal 15 Juni 2021 dari https://www.csis.or.id/publications/o ptimizing-the-distribution-of-thesocial-assistance-program-duringthe-covid-19-pandemic

Indonesia Corruption Watch. (2020). Survei bansos di DKI: Sembako habis dalam satu minggu. Diakses pada 29 November 2020 dari https://antikorupsi.org/id/berita

Kementerian Energi dan Sumber Daya Mineral. (2021). Bagian perlindungan sosial, pemerintah bebaskan tagihan pelanggan listrik 450 va dan beri keringanan pelanggan 900VA bersubsidi. Diakses pada tanggal 15 Juni 2021 dari 
https://www.esdm.go.id/id/media-

center/arsip-berita/bagian-

perlindungan-sosial-pemerintah-

bebaskan-tagihan-pelanggan-listrik-

450-va-dan-beri-keringanan-

pelanggan-900va-bersubsidi

Kementerian Keuangan (2020). DPR sahkan perppu no $1 / 2020$ jadi undang-undang karena sudah memenuhi syarat-syarat produk hukum. Diakses pada tanggal 15 Juni 2021 dari http://kemenkeu.go.id/publikasi/berit a/dpr-sahkan-perppu-no-1-2020jadi-undang-undang-karena-sudahmemenuhi-syarat-syarat-produkhukum

Kementerian Sosial. (2017). Pedoman umum pelaksanaan sistem layanan dan rujukan terpadu untuk perlindungan sosial dan penanganan kemiskinan. Jakarta: Kementerian Sosial.

Khalid, I. (19 Juni 2020). BLT Rp 600.000 Hanya Dibagikan Rp 150.000, Warga Laporkan Kepala Desa ke Kejaksaan. Kompas. Diakses pada tanggal 15 Juni 2021 dari https://regional.kompas.com/read/20 20/06/19/08261781/blt-rp-600000hanya-dibagikan-rp-150000-wargalaporkan-kepala-desa-ke?page =all

Kurniawan, A. (2008). Transformasi Pelayanan Publik. Yogyakarta: Pembaruan.

Lembaga Ilmu Pengetahuan Indonesia. (20 Agustus 2020). Survei Ekonomi Rumah Tangga Indonesia di Masa Pandemi Covid-19. Diakses pada tanggal 15 Juni 2021 dari http://lipi.go.id/berita/surveiekonomi-rumah-tangga-indonesiadi-masa-pandemi-covid-19/22121

Lestary, J.B., Indira, S., Dewa, A.W., Yose, R.D. (2020). Bantuan sosial ekonomi di tengah pandemi covid-19: sudahkah menjaring sesuai sasaran?. CSIS Commentaries ECON.

Mufidah, A. (2020). Polemik pemberian bantuan sosial di tengah pandemic Covid 19. Buletin Hukum \& Keadilan, 4(1), 159-166.

Negara, T. A. S. \& Nuswardani, N. (2014). Analisis perkara penyimpangan penyaluran dana bantuan sosial kemasyarakat oleh pemerintah daerah. Rechtidee, 9(2), 154-168.

Novika, S. (29 Mei 2020). Segudang Masalah "Macet" BLT Dana Desa: Dari Teknis hingga Politik. Kompas. Diakses pada tanggal 20 Desember 2020 dari https://finance.detik.com/beritaekonomi-bisnis/d5033554/segudang-masalah-macetblt-dana-desa-dari-teknis-hinggapolitik

Peraturan Menteri Desa, Pembangunan Daerah Tertinggal, dan Transmigrasi Republik Indonesia Nomor 6 Tahun 2020 Perubahan atas Peraturan Menteri Desa, Pembangunan Daerah Tertinggal, dan Transmigrasi Nomor 11 Tahun 2019 Tentang Prioritas Penggunaan Dana Tahun 2020. Jakarta.

Peraturan Menteri Kesehatan Republik Indonesia Nomor 9 Tahun 2020 Pedoman Pembatasan Sosial Berskala Besar dalam rangka Percepatan Penanganan Corona Virus Disease 2019 (Covid-19). Jakarta.

Peraturan Menteri Keuangan Republik Indonesia Nomor 254 /PMK.05/2015 Belanja Bantuan Sosial pada Kementerian Negara/Lembaga. Jakarta.

Peraturan Pemerintah Pengganti Undang-Undang Republik Indonesia 
Nomor 1 Tahun 2020 Tentang Kebijakan Keuangan Negara dan Stabilitas Sistem Keuangan untuk Penanganan Pandemi Corona Virus Disease 2019 Covid-19) dan/atau dalam rangka Menghadapi Ancaman Yang Membahayakan Perekonomian Nasional dan/atau Stabilitas Sistem Keuangan.

Prakerja. (2020) Apa itu kartu prakerja?. Diakses pada tanggal 15 Juni 2021 dari https://prakerja.go.id/tentangkami

Purnia, S. D., Rahmatullah, S., \& Rifai, A. (2019). Pengembangan Implementasi Aplikasi Bantuan Sosial Berbasis Mobile Pada Dinas Sosial. Indonesian Journal on Computer and Information Technology, 4 (2).

Qadri, R., A. (2019). Menakar model pembelian langsung rumah negara di Indonesia. Jurnal Pajak Dan Keuangan Negara, 1(1), 1-20.

Rahmansyah, W., Qadri, A. R., Resa, \& A. S., Ikhsan, S. (2020). Pemetaan permasalahan penyaluran bantuan sosial untuk penanganan covid-19 di Indonesia. Jurnal Pajak dan Keuangan Negara, 2(1), 90-102.

Ridhoi, A. M. (3 Juli 2020). Ragam masalah penyaluran bansos covid19 yang jadi sorotan Jokowi. Katadata. Diakses pada tanggal 15 Juni 2021 dari https://katadata.co.id/muhammadri dhoi/berita/5eff37fe0ff80/ragammasalah-penyaluran-bansos-covid19-yang-jadi-sorotan-jokowi

Robot, Y., \& Toreh, R. (14 Mei 2020). PKH, PHK dan setumpuk masalah. Manado Post. Diakses pada tanggal 15 Juni 2021 dari https://manadopost.jawapos.com/o pini/14/05/2020/pkh-phk-dansetumpuk-masalah

Saiful Munjani Research and Consulting (2020). Wabah covid-19: efektivitas bantuan sosial. Jakarta: SMRC

Santoso, S., Informatika, M., \& Kisaran, A. R. (2019). Sosial untuk keluarga miskin dengan metoda simple additve weighting (SAW). Journal of Science and Social Research, II(I), 2128.

Satuan Tugas Penanganan Covid-19. (2021). Perkembangan kasus covid 19 di Indonesia per tanggal 29 Maret 2021. Diakses pada tanggal 15 Juni 2021 dari https://www.Covid19.go.id/petasebaran

Silalahi, R. (2020). Cerita dari pelosok negeri: "problematika penyaluran bantuan sosial pemerintah dalam penanganan Covid19 \& pemulihan ekonomi di masyarakat". Catatan IGJ Indonesia Dalam Pusaran Covid19. Diakses pada tanggal 15 Juni 2021 dari https://igj.or.id/cerita-dari-pelosoknegeri-problematika-penyaluranbantuan-sosial-pemerintah-dalampenanganan-covid19-pemulihanekonomi-di-masyarakat/

Sitanggang, B., Tangdililing, A.B., Maryuni, S. (2014). Implementasi kebijakan penyaluran hibah dan bantuan sosial kemasyarakatan di kabupaten kubu raya. Jurnal Tesis PMIS-UNTAN.

Sugiarto, E. C. (2020). Menjaga momentum pemulihan ekonomi. Diakses pada tanggal 15 Juni 2021 dari https://setkab.go.id/menjagamomentum-pemulihan-ekonomi

Sumodiningrat, G. (1999). Jaring pengaman sosial dan pemberdayaan masyarakat. Jurnal Ekonomi dan Bisnis. 13, 3-25 
Suwiknyo. (2020). Problematika penyaluran BLT Dana Desa. Diakses pada tanggal 15 Juni 2021 dari https://infoanggaran.com/detail/problematika-penyaluran-blt-danadesa

Syarifudin, A. (5 Mei 2020). Penerima kartu sembako di Bantul tak bisa cairkan bantuan. Tribun Jogja. Diakses pada tanggal 15 Juni 2021 dari https://jogja.tribunnews.com/2020/0 5/05/penerima-kartu-sembako-dibantul-tak-bisa-cairkanbantuan?page $=3$

Tanjung, C., A. (1 Juli 2020). Warga lapor dana blt corona dipotong, Pemprov Riau: tidak ada pemotongan. Detiknews. Diakses pada tanggal 15 Juni 2021 dari https://news.detik.com/berita/d5075859/warga-lapor-dana-bltcorona-dipotong-pemprov-riautidak-ada-pemotongan

Teja, M. (2020). Permasalahan keakuratan data penerima bantuan sosial covid19. Info Singkat Kajian Singkat Terhadap Isu Aktual dan Strategis 12, 13-18.

Thomas, V., F. (19 Juni 2020). Masalah kartu prakerja: Gelombang IV ditunda. Tirto.id. Diakses pada tanggal 15 Juni 2021 dari https://tirto.id/masalah-kartuprakerja-gelombang-iv-ditundainsentif-dievaluasi-fJzj

Tim Nasional Percepatan Penanggulangan Kemiskinan. (2020). Ringkasan kebijakan kecukupan dan cakupan manfaat bantuan sosial pada masa pandemi covid-19. Diakses pada tanggal 15 Juni 2021 dari http://www.tnp2k.go.id/download/1
409Kecukupan\%20dan\%20Cakupan \%20Manfaat\%20Bantuan\%20Sosial \%20pada\%20Masa\%20Pandemi\%20 Covid-19.pdf

Umasugi, R. A. (2 Oktober 2020). Masalah Penyaluran Bansos DKI Tak Sesuai Kebutuhan Hingga Warga Lebih Butuh Uang Tunai. Kompas. Diakses pada tanggal 15 Juni 2021 dari https://megapolitan.kompas.com/re ad/2020/10/02/20371651/masalahpenyaluran-bansos-dki-tak-sesuaikebutuhan-hingga-wargalebih? page =all

Wijaya, L.D. (2 Oktober 2020). Survei bansos di DKI: sembako habis dalam satu minggu. Tempo. Diakses pada tanggal 15 Juni 2021 dari https://metro.tempo.co/read/13924 02/survei-bansos-di-dki-habisdalam-satu-minggu 